Article

\title{
Awakening Christian Discipleship: Gleanings from an Experiment in Interreligious Education
}

\author{
Kendra Fredrickson-Laouini
}

Citation: Fredrickson-Laouini, Kendra. 2021. Awakening Christian Discipleship: Gleanings from an Experiment in Interreligious Education. Religions 12: 75. https://doi.org/10.3390/rel12020075

Academic Editor: Stephen G. Parker Received: 4 December 2020 Accepted: 21 January 2021 Published: 24 January 2021

Publisher's Note: MDPI stays neutral with regard to jurisdictional claims in published maps and institutional affiliations.

Copyright: (c) 2021 by the author. Licensee MDPI, Basel, Switzerland. This article is an open access article distributed under the terms and conditions of the Creative Commons Attribution (CC BY) license (https:// creativecommons.org/licenses/by/ $4.0 /)$.
Practical Theology, Claremont School of Theology, Claremont, CA 91711, USA; kfredrickson-laouini@cst.edu; Tel.: +1-909-542-7919

\begin{abstract}
Through autoethnographic research, this article argues that interreligious education is integral to Christian discipleship and that living in a multi-religious world demands more than knowledge of the religious other. To live fully into a Christian identity in a multi-religious world demands interreligious education.
\end{abstract}

Keywords: theology; interreligious; education; discipleship; autoethnography

\section{Introduction}

Eleven years ago, I led a 5-week series on major world religions with middle school and high school students in a United Methodist Church in rural north-central Missouri. The series culminated in an experiential learning weekend (one for middle schoolers and one for high schoolers) where we visited Muslim, Buddhist, Jewish, and Orthodox Christian houses of worship in Kansas City, Missouri. This series and subsequent trip served as vehicle for deep reflection on our Christian faith (and, in particular, on our practices as United Methodist Christians) and caused an awakening of our Christian discipleship. This teaching series was our first engagement with interreligious education and over the last decade has had long-term effects on those who participated, especially me. In this paper, I argue that to live fully into a Christian identity in a multi-religious world demands interreligious education, and I support this argument through autoethnography, a practical theological method of research.

\section{Methodology and Limitations}

My understanding of practical theology has been formed by more than twenty years of work in youth ministry and religious education, by John Wesley's theology, by the Methodist church, and by the work of Kathleen Greider, Richard Osmer, Bonnie MillerMcLemore, and others. I was introduced to practical theology as an academic discipline by Kathleen Greider and was eager to understand it as more than a way of life. As I read Richard Osmer's Practical Theology: An Introduction the first time as part of Dr. Greider's class, I had an aha moment. I realized I was a practical theologian. Osmer's four-point frame for understanding (and doing) practical theology, (1) the descriptive-empirical task/what's going on? (2) the interpretive task/why is this going on? (3) the normative task/what ought to be going on? and (4) the pragmatic task/how might we respond ${ }^{1}$, made perfect sense. This was the way I had intuitively understood ministry-specifically, ministry with young people.

Renowned practical theologian Bonnie Miller-McLemore outlined four different ways to understand practical theology: (1) as an activity of believers; (2) as a method of religious leaders; (3) as a curricular area focused on ministerial practice; and (4) as an academic discipline supported by scholars seeking to uphold the first three. She writes, "Each understanding

1 (Osmer 2008, location 92 of 3256, Kindle) 
points to different spatial locations, from daily life to library and fieldwork to classroom, congregation, and community, and, finally, to academic guild and global context." ${ }^{2}$ In Dr. Greider's class, I was learning that practical theology moves between and within theory and practice grounded in particular contexts with particular groups of people. I discovered that it was holistic in that it pushes practitioners to self-reflection and deep understandings of relationships, all the while acknowledging that there is always more to learn and new insights to discover. It is listening, encouraging, and problem-solving.

These definitions of practical theology support autoethnographic research. By integrating personal experience, acknowledging a researcher's bias, and embracing the power of storytelling into the messy existence of human experience, autoethnographers can escape the pitfalls of representation and are empowered to question salient ideas, theories, and tropes embedded within culture through the lens of their own experiences. Even with its limitations, I choose autoethnography because it supports and encourages the unique contributions of a feminist approach to research —one that integrates both heart and mind and is wrought with potential for political and cultural change and healing. Autoethnography offers me a tool for claiming (or re-claiming) my voice as a religious leader, as an advocate for the marginalized, and as a woman navigating the contours of her own faith tradition. I also do autoethnographic research because it is inherently accessible. The power of accessibility allows readers to make meaning of often complex issues, emotions, and experiences-thus allowing social change, one person at a time. Autoethnography, in this light, can be pastoral and practical and relational. It can be a perfect research method for practical theologians. I have a lifetime of experience in and with the Church, and I have nearly a decade of interreligious education. These experiences empower and motivate me to utilize autoethnographic research as a practical theological tool in service to the Church.

I do, however, recognize the limitations to my approach. Since the research is limited to my own experience, it is limited also to my conclusions. The stories are written from a white, female, Protestant Christian, United Methodist, American, mid-western lens. This article might resonate more with readers of similar experience or may be primarily of interest to those seeking the flourishing and witness of the church in the world. Many scholars may consider this methodology insufficiently theoretical and too personal, while others may find it not literary or artful enough. Autoethnographers seek to balance theory and emotion to facilitate and continue important conversations. This project has sought to do that.

\section{Discussion}

In roughly my seventeenth year in youth ministry and long before I had ever heard of interreligious education or practical theology, I was serving a mid-sized United Methodist Church in north-central Missouri. A few years prior to that, I had begun questioning church structure and the notion of youth ministry. I wondered if we were truly making disciples by feeding students pizza, playing silly games, and reading Bible stories. My students were not being challenged, and I needed to change things up. I needed to engage students with new stories and push them to make connections between the faith they claimed and the world in which they lived. At the same time, my own interreligious awakening was taking place and I decided that perhaps I should take them on the journey with me.

With renewed interest in a book written by renowned United Methodist pastor, Adam Hamilton, that I had read a few years prior, a five-week series and the experiential weekend on major world religions was born. Hamilton writes, " ... it is essential that Christians seek to understand the faiths of others- to know how these faiths are similar to and different from their own faith - and to use that understanding to build bridges with others so that we might grow in our faith, seek peace in our world, love our neighbor, and find positive ways to share the gospel." ${ }^{3}$ While Hamilton's words might be criticized by interreligious 
educators for his interest in "sharing the gospel," I share this story because it served as a way into interreligious education for me. Many Christians I know might be fearful of interreligious engagement, and so it was with this blessing from a respected United Methodist pastor and my knowledge of engaging young people in religious learning that I decided to culminate the series in an experiential learning weekend that pushed our newly learned religious literacy to life. What resonated with me in that moment were the words "so that we might grow in our faith."

In organizing this teaching series and interfaith weekend, I was sure I would get pushback from parents and congregants in the small farming community-first, for teaching about other religions; second, and especially, for wanting to take adolescents to other houses of worship. I did not. In fact, parents came out of the woodwork to volunteer for the weekend-something that rarely happens in youth ministry. There are not many adults willing to give up their weekend to spend two nights with teenagers sleeping on a church floor, but for this particular weekend, they did. Interestingly too, many of the volunteers were parents who were not "the regulars." I saw this as evidence that people are hungry for interreligious education, and perhaps especially those who are less churched. Renowned pluralist, Diana Eck, affirms, "The people in our neighborhoods are often ahead of the religious leadership in desiring practical opportunities for dialogue and understanding of their neighbors' faith and world religions." ${ }^{4}$ So, much to my surprise, the weekend was met with enthusiasm rather than opposition.

The middle school student weekend began on Purim (a Jewish celebration that commemorates the saving of the Jewish people as told in the book of Esther in the Hebrew Bible), which was the perfect night for middle schoolers to experience a Jewish shabbat service, as it involved noise makers, and booing and cheering. Following the service, we were invited to participate in a fellowship time with snacks and conversation. The elderly cantor engaged the students in a deep, theological conversation on the nature of God, and the "seductive" nature of the idea of God incarnate. His ability to capture their attention and to challenge them to know their faith story was incredible to witness. He implored again and again, "You need to know your story." When we went back to the church to sleep that night, we processed the shabbat service, and one of the parent chaperones shared with the students how moved she was by the cantor and how she could not stop thinking about his words. She explained, "I'm a Christian because my parents are Christian. That's not a very good story. I need to know my story, and so do you. I hope you are appreciating this experience and really thinking about your story. This is important" (paraphrased).

The next day, on a Saturday, we visited a mosque and a Buddhist temple. At the mosque, we were greeted by several members of the congregation who gave us a tour, then taught us about prayer practices and beliefs. Students were brought into the prayer space and encouraged to ask questions-no question was off the table and after some shy silence, the students finally opened up, asking hard questions about terrorism, about women and the wearing of head coverings, and dietary practices. Our hosts were eager to respond. Our time at the mosque concluded with an opportunity to witness salat (Muslim prayers). Later that day, we visited a Buddhist temple for an hour-long time of guided meditation. If you have ever had the opportunity to spend an hour in quiet time with middle-school-aged students, you will not be surprised that their takeaway from this visit was largely concerned with the presence of a small dog in the Temple.

On Sunday, the middle schoolers visited a Roman Catholic Church for an early Sunday service (the high school students visited a Greek Orthodox Church); then, we headed to Adam Hamilton's United Methodist Church of the Resurrection for a mid-morning service. At the Catholic church, students were impressed by the elaborate décor, the physical gestures, and the liturgy. The visit to Mass inspired reflection on United Methodist worship and the order in which we organize our worship services, questions that had never been asked before. Our local church's average Sunday morning worship attendance was around

4 (Eck 2000, p. 141) 
250 in two services; the Church of the Resurrection averaged approximately 10,000 in worship each weekend in five services. Prior to this, my students had never imagined being part of a church so large.

Of course, not all the students in the youth group were able to attend our interreligious weekend, so on the Sunday night following our trip, we continued the conversation on other religious traditions and on their experience. I asked the students to share with others what they had learned or observed. One of my students, a noisy, unruly, hilarious 12-yearold girl, quickly responded enthusiastically and confidently with, "I learned that Muslims and Jews are more Christian than we are." I asked her to tell us more about that (as was often my response). She stood up and went on to explain her answer. She asked, "Girls, how many of you have ever played Mary in the Christmas pageant?" Several hands went up, and she asked, "What did we wear on our heads to imitate Mary? Who covers their heads? Muslim women!" Then she asked, "How many of you had bacon for breakfast? Or at least ate pork sometime in the last week? Jesus was Jewish. He didn't eat pork. We eat pork. Jews and Muslims don't. How many times have you prayed today? Muslims and Jews pray a lot more than that. See! They're more Christian than we are." Two years later, this same student sent me a Facebook message asking for help with writing her first research paper-a requirement for 8th grade graduation. I had moved to California to pursue a Master's degree in interreligious studies, and she wanted my email address so I could proofread her paper, titled, "Christians and Muslims: Not as Different as You Think." While my students and I had a lot more to learn, particularly about monolithic interpretations of others, essentializing, and generalizing, the weekend experience started the conversations and launched my own academic pursuits.

The high school experience produced similar responses. Their reflections were more mature and their questions more sophisticated, but their learning was just as significant. Students struggled with the unique nature of Jesus and salvation; they wrestled with chosenness and Abrahamic traditions and wondered if God was more okay with Abrahamic traditions than others. I was witnessing true reflection and curiosity, not only about other traditions but about their own theology, ideology, and church teachings. These students were asking questions about the origins of their beliefs and I could see their discipleship awakening.

A year or so after the Facebook message from the middle schooler, I got message from a former high schooler. This young woman was now in college and dating a Muslim. She was concerned because she had never dated anyone outside of Christianity and she asked me to remind her of what we had talked about all those years ago-particularly about the relationship between Christians and Muslims. I shared a quick, encouraging response and corresponded several times through the years as she and her Muslim boyfriend stayed together all through their undergraduate studies, and then graduate school, then engagement, then marriage. Throughout their courtship, she would message me with more questions - questions about cultural expectations (such as her parents drinking wine and his never drinking), about my marriage and pushback we may have received from friends and family (my husband is Muslim), and about our wedding and whether we had integrated Muslim and Christian practices in the ceremony. Theirs was a beautiful ceremony, and I am convinced that our little interreligious course and weekend experience, while rudimentary, played a small role in their marriage and in the ways their families have come together. She and her family are still Christian. He and his family are still Muslim. Yet they are united, just as my own family.

Episcopal priest and Professor of Practical Theology and Religious Education at Claremont School of Theology Sheryl Kujawa-Holbrook says of interreligious education, "For Christians to thrive in the midst of religious pluralism we need to understand and to articulate our own faith on a deeper level, we need to make it our business to study the beliefs and practices of others, we need skills in navigating other traditions and cultures, and we need to build authentic partnerships in our local communities ... What would a 
Christian church look like that loved all God's people as much as it did its own members? The task of interreligious learning is to equip us to live more fully into this vision." ${ }^{5}$

This experiential weekend served as the impetus to living into that vision. My students and I were beginning to articulate our own faith more deeply, we had made it our business to study the beliefs and practices of some of the folks in our extended community, and we were beginning to gain the skills to navigate other traditions. It was a start. It was not something to do and check off our list as though it was finished. It was an initial integration of interreligious education in a Methodist youth ministry program in Missouri, and it awakened our understanding of Christian discipleship.

\section{Results}

That one lesson series demonstrated that interreligious education should be more than a one-time youth ministry experience. I realized then that to live in a multi-religious world demanded that we must begin to holistically integrate interreligious education into all of the ways we do church-through sermons, music, Sunday school, small groups, social justice endeavors, and more-in order to be better disciples. The epitome of Christian privilege is not seeing the religious other. Before I developed this lesson plan, I was having an interreligious awakening. You know, those moments when you suddenly realize your doctor, your stylist, your neighbor, your grocery store owner, or just about anyone in your life, practices a different religion? These are critical developmental moments when you see beyond yourself. These moments have the capacity to move you. It is the realization that the world is diverse-not just an intellectual knowledge, but a lights-on in a dark room, blinding kind of self- and other-realization. You wonder how you had never noticed before, and you start to ask questions. This is what was happening with me when I planned the series, and this is what was happening with my students after it. They were beginning to see a world beyond their small, mostly white, mostly Christian, agricultural community situated in the heart of the United States. They were beginning to wrestle with religious pluralism.

Perhaps no one has done a better job at pushing the conversation on religious pluralism out of the academy than Harvard professor Diana Eck. As the creator and director of Harvard's Pluralism Project, Eck offers an accessible approach to religious pluralism. In her seminal 2001 book, A New Religious America: How a "Christian Country" Has Now Become the World's Most Religiously Diverse Nation, Eck argues that religious pluralism is in the DNA of America and at the core of what it means to be American, thereby inspiring interreligious awakenings that lead to more purposeful dialogue and education. She writes, "Just as our religious traditions are dynamic, so is the very idea of America. The motto of the republic, E Pluribus Unum, 'From Many, One,' is not an accomplished fact but an ideal that Americans must continue to claim. The story of America's many peoples and the creation of one nation is an unfinished story in which the ideals articulated in the Declaration of Independence and the Constitution are continually brought into being." ${ }^{\prime \prime} \mathrm{A}$ newfound knowledge of the mere existence of the religious other epitomizes Christian privilege and exemplifies the way many Christians live-isolated and as solitary holders of the Truth. This makes Eck's accessible work increasingly and continuously important as we continue to write America's unfinished story.

Interreligious dialogue is what comes after such awakenings. It can be both formal and informal. To be sure, interreligious dialogue takes place in everyday, ordinary lifein barber shops, grocery stores, apartment complexes, and households. This informal dialogue can lead to deep theological inquiry or can lead to simple mere tolerance or coexistence. Left unexplored, it can also be exploited by fear mongers who seek disruption, public scare, and discrimination. Organizational interreligious dialogue is more intentional in nature and asks participants to engage fully, honestly, and humbly with the religious

(Kujawa-Holbrook 2014, p. xix)

6 (Eck 2001, p. 9) 
other. This formal interreligious engagement takes place in churches, mosques, temples, and shared public spaces as well. It aims to build and deepen relationships, to work for the greater good of all humanity, and to ground and support people in each of their respective traditions. It does not require one to practice a particular religious tradition, but if a participant is part of a religious community, it could most certainly deepen one's faith. Professor of Roman Catholic Thought and Interreligious Dialogue at Temple University, Leonard Swidler, developed a philosophical and pedagogical framework for interreligious dialogue with his "Dialogue Decalogue", which first appeared in the Journal of Ecumenical Studies in 1983. ${ }^{7}$ The "Dialogue Decalogue" outlines ten commandments for dialogue, whereby dialogue becomes a vehicle for new revelation.

Interreligious education requires religious practitioners to dig deeply into their own faith and practice and includes the articulation of one's own faith (even, and especially, in the uncertainty of the adherent). Outside of religious communities, interreligious education is also an interdisciplinary field and pedagogical practice. It can be found in the academy, in interreligious organizations, in houses of worship, as well as in many households. Interreligious education is more than a recognition of religious diversity and formal and informal interreligious experiences. Interreligious education is comprehensive and ongoing. Episcopal priest and Executive Director of United Religions Initiative, Victor Kazanjian, affirms this, noting, "Only through interfaith education which encourages us to embrace our diversity and claim our interdependence will we learn about each other, form true relationships, and build communities of mutual respect that are essential for establishing cultures of peace." ${ }^{8}$ Judith Berling, professor at Berkeley's Graduate Theological Union, implores Christians engaging in interreligious education to first speak from their own experiences and then to build the skills necessary to listen to and understand people of different religious traditions and backgrounds. She affirms that interreligious education is not a finite task but is part of the formation of Christian character. ${ }^{9}$

In Moving Beyond the Impasse: Reorienting Ecumenical and Interfaith Relations, Methodist theologian Wesley Ariarajah defines interreligious education as equipping religious communities with the resources needed to face the challenges of an interreligious world, identifying four questions to guide interreligious education: Who is my neighbor? Who am I in relation to my neighbor? What is the place of my own faith? What might be the ultimate goal in relating to my neighbor? Ariarajah then suggests three elements that should be included in the interreligious learning process: learning about the faith and practices of other religious traditions from adherents of that tradition, learning about the history and issues (including doctrinal issues) that have plagued relationships between given religious traditions, and learning through direct experience of worshiping communities outside one's own tradition. ${ }^{10}$ He affirms, " ... real interfaith learning happens not only through reading but also, and more so, by having the experience of meeting 'the other' who is part of our own humanity. In other words, interfaith education is not only concerned with increasing knowledge but also with changing perceptions, removing prejudices, healing memories, and building community ... the purpose of all education and learning is transformation." 11 In sum, interreligious education is not just about forming friendships and mutual respect, but is about transformation, flourishing, self-discovery, and interdependence.

Like interreligious education, Christian discipleship is also about transformation. It is about following in the footsteps of Jesus-knowing who he was, what he taught, what he did, and how he loved, then seeking to live in the same way. For Christians seeking to be disciples of Jesus Christ, the Bible is the primary authority and Jesus' words and actions

7 (Swidler et al. 2007, location 634 of 4332, Kindle)

(Kazanjian 2017, p. vii)

(Berling 2004, p. 77)

(Ariarajah 2018, p. 99)

11 (Ariarajah 2018, p. 99) 
are the example for faithful living. Jesus defines discipleship as love. In Jesus' farewell discourse in the Gospel of John, he said, "I give you a new commandment: Love each other. Just as I have loved you, so you also must love each other. This is how everyone will know that you are my disciples, when you love each other."12 And love, according to Christian Scripture, is patient, kind, happy with the truth; and it puts up with, hopes for, and endures all things. Love is not jealous, braggadocious, arrogant, rude, irritable, or happy with injustice. Love does not keep a record of complaints or seek its own advantage, and love never fails. ${ }^{13}$ This kind of love is not a mushy sentiment-rather, it is transformative.

All those years ago, my students and I began a journey of transformation in our minds, hearts, spirits, and actions. Even though we had attended church faithfully, loved one another, and sought to walk in ways that were life-giving, we had become far too insular in our thinking and understanding. One five-week lesson series and one experiential weekend opened the doors to a decade of transformation. For me, it led to Claremont School of Theology to pursue first a Master's degree in Interreligious Studies and then a doctoral degree in Practical Theology and Interreligious Education. For my students who are now all grown up, it led to better questions, more empathy, interreligious families, and a new posture of openness for a wider world. It led to transformative Christian discipleship, the kind that knows your neighbor, hears your neighbor, sees your neighbor, and loves your neighbor. Interreligious education was integral to our discipleship, and our multi-religious world demands such a response.

Funding: This research received no external funding.

Institutional Review Board Statement: The study was conducted according to the guidelines of the Declaration of Helsinki, and approved by the Institutional Review Board of Claremont School of Theology.

Conflicts of Interest: The author declares no conflict of interest.

\section{References}

Ariarajah, S. Wesley. 2018. Moving Beyond the Impasse: Reorienting Ecumenical and Interfaith Relations. Minneapolis: Fortress Press.

Berling, Judith A. 2004. Understanding Other Religious Worlds: A Guide for Interreligious Education. Maryknoll: Orbis Books.

Eck, Diana. 2000. Dialogue and Method: Reconstructing the Study of Religion. In A Magic Still Dwells: Comparative Religion in the Postmodern Age. Edited by Kimberley C. Patton and Benjamin C. Ray. Berkeley: University of California Press, p. 141.

Eck, Diana. 2001. A New Religious America: How a "Christian Country" has Now Become the World's Most Religiously Diverse Nation. San Francisco: HarperSanFrancisco.

Hamilton, Adam. 2005. Christianity and World Religions: Wrestling with Questions People Ask. Nashville: Abingdon Press.

Kazanjian, Victor H., Jr. 2017. Prologue. In Interfaith Education for All: Theoretical Perspectives and Best Practices for Transformative Action. Edited by Duncan R. Wielzen and Ina Ter Avest. Rotterdam: Sense Publishers.

Kujawa-Holbrook, Sheryl A. 2014. God Beyond Borders: Interreligious Learning among Faith Communities. Eugene: Pickwick Publications. Miller-McLemore, Bonnie J., ed. 2014. The Wiley Blackwell Companion to Practical Theology. West Sussex: John Wiley \& Sons.

Osmer, Richard. 2008. Practical Theology: An Introduction. Grand Rapids: Wm. B. Eerdmans.

Swidler, Leonard, K. Duran, and R. Firestone. 2007. Trialogue: Jews, Christians and Muslims in Dialogue. New London, CT: Twenty-third Publications.

12 John 13: 34-35 (CEB).

13 1 Corinthians 13: 4-8 (CEB). 